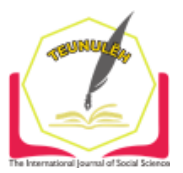

Jurnal Ilmiah Teunuleh

The International Journal of Social Sciences

Vol. 2, Issue. 2, June 2021

E-ISSN: $2746-4393$

\title{
CONSISTENCY ANALYSIS OF PLANNING AND BUDGETING AND THEIR IMPLICATIONS ON PERFORMANCE ACHIEVEMENTS AT BAPPEDA OF NAGAN RAYA REGENCY
}

\author{
M. Ikmal Sarnando ${ }^{1}$ \\ Economic Development, Faculty of Economic, University of Teuku Umar, Meulaboh \\ muhammadikmal2828@gmail.com \\ Yasrizal $^{2}$ \\ Economic Development, Faculty of Economic, University of Teuku Umar, Meulaboh \\ yasrizal@utu.ac.id \\ corresponding author
}

\begin{abstract}
This research intends to find out how consistent planning and budgeting is and also to see performance achievements at the Nagan Raya District Development Planning Agency in 2018-2020. In calculating the 2015 inter-program and manuscript activities, it is carried out using the Matrik Consolidated Planning and Budgeting (MKPP) and the Cause is not synchronized between programs and activities between manuscripts conducted with detailed interviews. The acquisition of conformity shows the conformity between planning and budgeting manuscripts in Bappeda Kbaupaten Nagan Raya is appropriate. The best suitability is in the RKA and DPA. The cause of inconsistency is caused by programs and activities that are not synchronized with each other and technical constraints on the ground and delayed central fund transfers. The results of the performance achievement analysis in Bappeda Nagan Raya Regency showed that overall both targets, programs, and activities were the same as the targets that had been determined.
\end{abstract}

Keywords: Consistency of Planning, Budgeting, Achievement of Performance Targets

\section{A. Introduction}

In order to resolve the turn of events, public authorities must have appropriate regulatory measures and be relied upon to have the option to assess the arrangements that it does. As the financial cycle develops, there is a sought-after expansion for information and markers that require accessibility of information to the local level. The 
information and instructions needed are in accordance with the plans that have been set.

In its preparation, an implementation cycle is needed, starting with knowing the right problem, imperative, goals and objectives to be achieved. Then, at that time the cycle must be carried out by an organizer who is proficient in his field. The 2004 SPPN stipulates that there are 5 (five) improvements to the preparation of archives that must be prepared by structuring agencies at the public and provincial levels, 1) Public/Regional Long-Term Development Plans (RPJMN/D) which are long-term archives for a period of time year. 2) The Community/Regional Medium-Term Development Plan (RPJMN/D) is a medium-term structuring archive for the next 5 years that contains a substantial description of the vision and mission of the regional head (for the common interest, at the regional and city levels). 3) Restra Inti, referred to as Restra for Regional Apparatus Work Units (Restra SKPD) which contains a description of the vision and mission of the head of the SKPD which is then obtained from the vision and mission of the Regional Government. The Head of Restra SKPD is more detailed in nature, that is, it comes to training because the extension is simpler, in accordance with the capacity and main obligations (tupoksi) of the organization concerned. Restra SKPD is a development of SKPD which compiles archives for a period of 5 years. 4) Government Work Plan (RKP) or Local Government Work Plan (RKPD) is an arrangement that describes the RPJM that contains strategies, projects and implementation for one year in accordance with the assets that can be accessed in that year, especially reserves. Then the RKPD is used as the basis for the preparation of the Regional Revenue and Expenditure Budget Plan (RAPBD). 5) Institutional Work Plans (RENJA) or Work Plans for Regional Apparatus Work Units (Renja SKPD), which are also an annual functional arrangement that contains a description of the restra made by each SKPD in accordance with its main tupoksi.

There are several details of the budgeting script that must be made, namely: 1) the general APBP policy (KUA) is a text that contains regulations for the division of income, expenditure and costs for a period of one year. 2) Priority and Temporary Budget Ceiling (PPAS) is a draft of the priority program and is a cost limit aimed at SKPD so that all programs become a reference for the implementation of preparing SKPD work plans and budgets (RKA-SKPD) before the Regional House of Representatives (DPRD) agree on this matter. 3) The Regional Revenue and Expenditure Budget (APBD) is the annual financial agenda of the regional government which is then approved by the DPRD and determined by regional regulations, namely for a period of one year, from January 1 to 
December 31. 4) The Work Plan and Budget (RKA) is a planning and budgeting document that contains income plans, expenditure plans, SKPD programs and activities as well as a financing plan as the basis for the preparation of the APBD. 5) The Budget Implementation Document (DPA) is a document that contains the income and expenditure of each SKPD which is then used as the basis for budget implementation by budget users.

Then, at the stages of implementing the steps for regulating provincial expenditures, in particular: 1) submission of environmental government arrangements identified with the overall APBD approach in the following fiscal year, particularly as a reason for planning the APBD Draft, the overall APBD strategy is directed by the RKPD. During the preparation of the RKPD, it is carried out through the completion of the Development Planning Deliberation (Musrenbang) which is carried out by the components of the public authority and subsequently includes or stimulates important regional goals, including universities, skilled affiliations, customs. pioneers, nonlegislative associations (NGOs), strict pioneers and the business world. 2) then, at that time the DPRD held a discussion related to the overall APBD strategy which was approved by the regional government, especially in the primary discussion of the RAPBD for the next fiscal year. 3) then, after that it depends on the overall preparation of the APBD which is not standard and agrees with the DPRD, then at that time the public body and DPRD review the Needs and Roof of Non-Fixed Expenditures (PPAS) which are then used. as a source of perspective in each SKPD. 4) The SKPD leadership who is the client of the later expenditure, then prepares the next year's RKA-SKPD, while still referring to the Short Expenditure Needs and Roof (PPAS) which have been controlled by the regional government and DPRD. 5) then the RKA-SKPD is then forwarded to the DPRD to be discussed in the implementation of the RAPBD primary discussion. 6) In addition, the consequences of the RKA-SKPD discussion are then conveyed to important officials in charge of regional accounts, particularly as material for the preparation of the provincial guideline draft (perda) which is identified with the APBD of next year. 7) the environmental government makes entries in accordance with the draft regional guideline (perda) of the APBD which is added with clarifications and supporting files to the DPRD. 8) then, at that time the dynamics chosen by the DPRD related to the draft regional regulation on $A P B D$ are finalized no later than one month before the implementation of the fiscal year. 


\section{B. Research Method}

\section{Research Approach and Design}

The approach and design that will be used in this research is descriptive qualitative research. In this study, data analysis was carried out in several stages as follows:

1. Collecting some data obtained in the field, both secondary and primary data and also the results of the study of related manuscripts in this study.

2. In resolving the problem of synchronizing planning and budgeting at the Regional Development Planning Agency (BAPPEDA) of Nagan Raya Regency, it was resolved by reviewing several bound texts, namely PPAS of Nagan Raya Regency for 20182020, RENJA of Bappeda of Nagan Raya Regency for 2018-2020, RKA Bappeda of Nagan Regency Raya 2018-2020 and DPA Bappeda Nagan Raya Regency 2018-2020. Then the results of the review of the bound texts are made and included in the form of a consolidated planning and budgeting matrix (MKPP), then the MKPP is made by synchronizing the planning and budgeting manuscripts of the Nagan Raya Regency Bappeda.

3. In determining the suitability of the texts, it is done by synchronizing between programs and activities as a whole. Activities are considered synchronous if they both have the same concerns, in other words they have the same goals and objectives. Measuring the consistency of programs and activities can be simplified as follows:

Table 1. Measurement of Planning and Budgeting Consistency

\begin{tabular}{|c|l|l|l|}
\hline \multirow{2}{*}{ No } & \multicolumn{2}{|c|}{ Programs and activities } & \multirow{2}{*}{ Conformity assessment } \\
\cline { 2 - 3 } & \multicolumn{1}{|c|}{ Manuscript A } & \multicolumn{1}{|c|}{ Manuscript B } & \\
\hline 1 & There is & There is & In accordance \\
\hline 2 & There is & There is not any & It is not in accordance with \\
\hline 3 & There is not any & There is & It is not in accordance with \\
\hline
\end{tabular}

Then in determining the overall level of consistency of the related documents is done by using the percentage technique, namely:

Consistency level $(\%)=\underline{\text { number of consistent activities } \times 100}$

\section{Total Activities}

The level of consistency based on percentage (Sugiono, 2003) are:

- Very Low : :0.0-19.9

- Low : 20.0-39.9 
Consistency Analysis of Planning and Budgeting and Their Implications on Performance...

- Enough : :40.0-59.9

- Good : $60.0-79.9$

- Very Good : : $80.0-100.0$

\section{Results and Discussions}

1. Conformity of Planning with Budgeting in Bappeda Nagan Raya Regency

The suitability of planning with budgeting is seen based on the suitability between priority texts and PPAS, RENJA, RKA and DPA.

Conformity of PPAS Priority Manuscripts with RENJA

The suitability of the PPAS manuscript with the National Development Planning Agency for Nagan Raya Regency 2018 - 2020 can be seen in the table below:

Table 2. PPAS conformity with the National Development Planning Agency for Nagan Raya $2018-2020$

\begin{tabular}{|c|c|c|c|c|c|c|c|c|}
\hline \multirow{2}{*}{ No. } & \multirow{2}{*}{\multicolumn{2}{|c|}{ Program Status }} & \multicolumn{2}{|c|}{2018} & \multicolumn{2}{|c|}{2019} & \multicolumn{2}{|c|}{2020} \\
\hline & & & Prog & Keg & Prog & Keg & Prog & Keg \\
\hline \multirow{2}{*}{1} & \multirow{2}{*}{ In accordance } & Amount & 10 & 67 & 14 & 102 & 16 & 126 \\
\hline & & $\%$ & 62,5 & 83,75 & 100 & 91 & 100 & 94 \\
\hline \multirow{2}{*}{2} & \multirow{2}{*}{$\begin{array}{l}\text { It is not in } \\
\text { accordance } \\
\text { with }\end{array}$} & Amount & 6 & 13 & - & 10 & - & 8 \\
\hline & & $\%$ & 37,5 & 16,25 & - & 9 & - & 6 \\
\hline
\end{tabular}

Source: PPAS and RENJA of Bappeda Nagan Raya Regency 2018 - 2020

\section{PPAS and 2018 RENJA compatibility}

In 2018 there were 16 programs and 68 activities in PPAS Bappeda Nagan Raya Regency, and there were 10 programs and 80 activities in the RENJA that year. Table 2 above shows that of the 16 programs in PPAS there are 10 programs that are consistent with the RENJA program so that the remaining 6 programs are inconsistent from the RENJA program, it can be said that $62.5 \%$ of programs in PPAS are in accordance with the RENJA program and $37.5 \%$ have not. according to the program in RENJA. Then from 68 activities in PPAS there are 67 activities that are consistent with RENJA activities, so that there are 13 inconsistent activities from RENJA activities, it can be said that $83.75 \%$ of activities in PPAS are in accordance with RENJA activities and $16.25 \%$ are not in accordance with RENJA activities. at RENJA. From this information, it is explained that in compiling PPAS it has not been based on the full RENJA. 


\section{PPAS and RENJA 2019 compatibility}

In 2019 there were 14 programs and 106 activities at PPAS Bappeda Nagan Raya Regency, and there were 14 programs and 112 activities in the RENJA that year. Table 2 above shows that of the 14 programs in PPAS there are 14 programs that are consistent with the RENJA program, it can be said that $100 \%$ of the programs in PPAS are in accordance with the RENJA program. Then from 106 activities in PPAS there are 102 activities that are consistent with RENJA activities, so that the remaining 10 activities are inconsistent from RENJA activities. So it can be said that $91 \%$ of activities in PPAS are in accordance with RENJA activities and 9\% are not in accordance with RENJA activities. From this information, it is explained that in compiling PPAS it has not been based on the full RENJA.

\section{PPAS and RENJA 2020 compatibility}

In 2020 there were 16 programs and 131 activities in PPAS Bappeda Nagan Raya Regency, and there were 16 programs and 134 activities in the RENJA that year. Table 2 above shows that of the 16 programs in PPAS there are 16 programs that are consistent with the RENJA program, so it can be said that $100 \%$ of the programs in PPAS are in accordance with the RENJA program. Then from 131 activities in PPAS there are 126 activities that are consistent with RENJA activities, so that there are 8 activities that are inconsistent with RENJA activities, it can be said that $94 \%$ of activities in PPAS are in accordance with RENJA activities and 6\% are not in accordance with RENJA activities. From this information, it is explained that in compiling PPAS it has not been based on the full RENJA.

\section{The Conformity of the RENJA Manuscript with the RKA}

The suitability of the RENJA manuscript with the RKA Bappeda of Nagan Raya Regency in 2018 - 2020 can be seen in the table below:

Table 3. Conformity of the RENJA with the RKA of Bappeda Nagan Raya 2018-2020

\begin{tabular}{|c|c|c|c|c|c|c|c|c|}
\hline \multirow{2}{*}{ No. } & \multirow{2}{*}{\multicolumn{2}{|c|}{ Status Program }} & \multicolumn{2}{|c|}{2018} & \multicolumn{2}{|c|}{2019} & \multicolumn{2}{|c|}{2020} \\
\hline & & & Prog & Keg & Prog & Keg & Prog & Keg \\
\hline \multirow{2}{*}{1} & \multirow{2}{*}{ In accordance } & In accordance & 10 & 72 & 14 & 97 & 12 & 94 \\
\hline & & $\%$ & 83,3 & 90 & 93,3 & 86,61 & 75 & 78,3 \\
\hline \multirow{2}{*}{2} & \multirow{2}{*}{$\begin{array}{l}\text { It is not in } \\
\text { accordance }\end{array}$} & In accordance & 2 & 8 & 1 & 15 & 4 & 26 \\
\hline & & $\%$ & 16,7 & 10 & 6,7 & 13,39 & 15 & 21,7 \\
\hline
\end{tabular}

Source: RENJA and RKA Bappeda Nagan Raya Regency 2018 - 2020 


\section{RENJA and RKA 2020 Compatibility}

In 2018 there were 12 programs and 76 activities in the Nagan Raya Regency RKA, and there were 10 programs and 80 activities in the RENJA of the Year. Table 3 above shows that of the 12 programs in the RKA there are 10 programs that are consistent with the RENJA program so that the remaining 2 programs are inconsistent from the RENJA program, it can be said that $83.3 \%$ of programs in the RKA are in accordance with the RENJA program and $16.7 \%$ have not. according to the program in RENJA. Then from 76 activities in RKA there are 72 activities that are consistent with RENJA activities so that the remaining 8 activities are inconsistent from RENJA activities, it can be said that $90 \%$ of activities in RKA are in accordance with RENJA activities and $10 \%$ are not in accordance with RENJA activities. From this information, it is explained that in compiling the RKA it has not been based on the full RENJA.

\section{RENJA and RKA 2019 Compatibility}

In 2019 there were 15 programs and 97 activities in the Nagan Raya Regency RKA, and there were 14 programs and 112 activities in that Year's RENJA. Table 3 above shows that of the 15 programs in the RKA there are 14 programs that are consistent with the RENJA program so that there is only 1 program that is inconsistent from the RENJA program, it can be said that $93.3 \%$ of the programs in the RKA are in accordance with the RENJA program and $6.7 \%$ have not. according to the program in RENJA. Then from 97 activities in RKA there are 97 activities that are consistent with RENJA activities so that there are 15 inconsistent activities from RENJA activities, it can be said that $86.61 \%$ of activities in RKA are in accordance with RENJA activities and $13.39 \%$ are not in accordance with activities in RENJA. RENJA. From this information, it is explained that in compiling the RKA it has not been based on the full RENJA.

\section{RENJA and RKA 2020 Compatibility}

In 2020 there are 12 programs and 96 activities in the Nagan Raya Regency RKA, and there are 16 programs and 120 activities in the RENJA that year. Table 3 above shows that of the 12 programs in RKA there are 12 programs that are consistent with the RENJA program so that the remaining 4 programs are inconsistent from the RENJA program, it can be said that $75 \%$ of programs in RKA are in accordance with the RENJA program and $15 \%$ are not in accordance with the program in RENJA. Then from 96 activities in RKA there are 94 activities that are consistent with RENJA activities so that the remaining 26 
activities that are inconsistent with RENJA activities, it can be said that $78.3 \%$ of activities in RKA are in accordance with RENJA activities and $21.7 \%$ are not in accordance with activities in RENJA. RENJA. From this information, it is explained that in compiling the RKA it has not been based on the full RENJA.

\section{Conformity of the RKA Manuscript with the DPA}

The suitability of the RKA script with the DPA of Bappeda Nagan Raya Regency in 2018 2020 can be seen in the table below:

Table 4. Conformity of the RENJA with the RKA of Bappeda Nagan Raya 2018 - 2020

\begin{tabular}{|c|c|c|c|c|c|c|c|c|}
\hline \multirow{2}{*}{ No. } & \multirow{2}{*}{\multicolumn{2}{|c|}{ Status Program }} & \multicolumn{2}{|c|}{2018} & \multicolumn{2}{|c|}{2019} & \multicolumn{2}{|c|}{2020} \\
\hline & & & Prog & Keg & Prog & Keg & Prog & Keg \\
\hline \multirow{2}{*}{1} & \multirow{2}{*}{ In accordance } & In accordance & 12 & 76 & 15 & 97 & 12 & 96 \\
\hline & & $\%$ & 100 & 100 & 100 & 100 & 100 & 100 \\
\hline \multirow{2}{*}{2} & \multirow{2}{*}{$\begin{array}{l}\text { It is not in } \\
\text { accordance } \\
\text { with }\end{array}$} & In accordance & - & - & - & - & - & - \\
\hline & & $\%$ & - & - & - & - & - & - \\
\hline
\end{tabular}

Source : RKA and DPA Bappeda Nagan Raya Regency 2018 - 2020

\section{Compatibility of RKA and DPA 2018}

In 2018 there were 12 programs and 76 activities in the Nagan Raya Regency RKA, and there were 12 programs and 76 activities in the DPA that year. Table 4 above shows that of the 12 programs in the RKA there are 12 programs that are consistent with the DPA program, so it can be said that $100 \%$ of the programs in the RKA are in accordance with the DPA program. Then from 76 activities in RKA there are 76 activities that are consistent with DPA activities, it can be said that $100 \%$ of activities in RKA are in accordance with DPA activities. From this information, it is explained that in compiling the RKA it has been based on the DPA completely.

\section{Compatibility of RKA and DPA 2019}

In 2019 there were 15 programs and 97 activities in the Nagan Raya Regency RKA, and there were 15 programs and 97 activities in the DPA that year. Table 4 above shows that from 15 programs in RKA there are 15 programs that are consistent with the DPA program, so it can be said that $100 \%$ of programs in RKA are in accordance with the DPA program. Then from 97 activities in RKA there are 97 activities that are consistent with DPA activities, it can be said that $100 \%$ of activities in RKA are in accordance with DPA 
activities. From this information, it is explained that in compiling the RKA it has been based on the DPA completely.

\section{Compatibility of RKA and DPA 2020}

In 2020 there are 12 programs and 96 activities in the Nagan Raya Regency RKA, and there are 12 programs and 96 activities in the DPA that year. Table 4 above shows that of the 12 programs in the RKA there are 12 programs that are consistent with the DPA program, so it can be said that $100 \%$ of the programs in the RKA are in accordance with the DPA program. Then from 96 activities in RKA there are 96 activities that are consistent with DPA activities, it can be said that $100 \%$ of activities in RKA are in accordance with DPA activities. From this information, it is explained that in compiling the RKA it has been based on the DPA completely.

From the results of adjustments to all planning and budgeting scripts in the Bappeda of Nagan Raya Regency in 2018-2020, it resulted in good conformity, namely the relevance of the planning and budgeting scripts was good or significant.

\section{Performance Achievements of the Nagan Raya Regency Bappeda}

Performance Achievements and Budget Realization for Nagan Raya Regency Bappeda in 2018

In 2018 from achieving targets, programs and activities by the Regional Development Planning Agency of Nagan Raya Regency have been carried out well although there are several planned activities that were not implemented due to technical constraints in the field, and the total budget in 2018 was Rp. 16,751,267,736,- (Sixteen billion seven hundred fifty-one million two hundred sixty-seven thousand seven hundred and six rupiah), in the amount listed there are direct expenditures and indirect expenditures. For indirect expenditure, which is Rp. 4,438,858,436,- (Four billion four hundred thirty eight million eight hundred fifty eight thousand four hundred and thirty six rupiah) and direct expenditure amounting to Rp. 12,312,409,300,- (Twelve billion three hundred twelve million four hundred nine thousand three hundred rupiah).

Overall, all activity costs by the Nagan Raya Regency Bappeda with a budget in 2018 have been realized in the amount of Rp. 13,973,308,814,- (thirteen billion nine hundred seventy three million three hundred eight thousand eight hundred and four rupiahs) which is equivalent to $83.42 \%$. 


\section{Performance Achievements and Budget Realization of Bappeda Nagan Raya Regency in 2019}

In 2019 from the achievement of targets, programs and activities by the Regional Development Planning Agency of Nagan Raya Regency have been carried out well, although there were several planned activities that were not carried out due to delayed central funds, and the total budget in 2019 was Rp. 21,753,542,308,- (Twenty-one billion seven hundred fifty-three million five hundred forty-two thousand three hundred and eight rupiahs), in the amount listed there are direct and indirect expenditures. For indirect expenditure, which is Rp. 6,190,013,508, - (Six billion one hundred ninety million thirteen thousand five hundred and eight rupiah) and direct expenditures amounting to Rp. 15,563,528,800,- (Fifteen billion five hundred sixty three million five hundred twenty eight thousand eight hundred rupiah).

Overall, all the costs of activities by Bappeda Nagan Raya Regency with a budget in 2019 were only realized amounting to Rp. 15,077,948,333,- (Fifteen billion seventyseven million Nine hundred forty-eight thousand three hundred and thirty-three rupiah) which is equivalent to $69.31 \%$. Low budget uptake due to delayed central transfers so that the realization of activities in 2019 will be realized in the 2020 budget year.

\section{Achievement of Performance and Realization of Bappeda Budget of Nagan Raya Regency in 2020}

In 2020 from the achievement of targets, programs and activities by the Regional Development Planning Agency of Nagan Raya Regency have been carried out well, and the total budget in 2020 is Rp. 10,696,438,370,- (Ten billion six hundred ninety-six million four hundred thirty-eight thousand three hundred and seventy rupiah), in the amount listed there are direct expenditures and indirect expenditures. For indirect expenditure, which is Rp. 3,841,110,704, - (Three billion eight hundred forty-one million one hundred and ten thousand seven hundred and four rupiah) and direct expenditure amounting to Rp. 6,855,327,666,- (Six billion eight hundred fifty five million three hundred twenty seven thousand six hundred and six rupiah). Overall, all activity costs by the Nagan Raya Regency Bappeda with a budget in 2020 have been realized in the amount of Rp. 10.230.217.380,- (Ten billion two hundred thirty million two hundred seventeen thousand three hundred and eighty rupiah) which is equivalent to $95.54 \%$. 


\section{Conformity of Planning and Budgeting and Implications for Performance Achievements of Bappeda Nagan Raya Regency}

From the results of the analysis of the suitability of planning and budgeting that has been carried out, it can be described as follows:

a. From the analysis of the suitability of PPAS with the RENJA of the Bappeda of Nagan Raya Regency in 2018-2020 it is quite good and appropriate. From the results of the analysis, it shows the suitability between programs as much as $87.5 \%$ while for the results of the analysis between activities as much as $89.6 \%$, which is a fairly good result, although there are several programs and activities that are still not in sync with each other, meaning that in the preparation of PPAS is still not based on the full RENJA.

b. From the analysis of the suitability of the RENJA with the RKA Bappeda Nagan Raya Regency in 2018-2020 it is quite good and appropriate. From the results of the analysis, it shows the suitability between programs as much as $83.39 \%$ while for the results of the analysis between activities as much as $84.97 \%$, which is a fairly good result, although there are several programs and activities that are still out of sync with each other, meaning that in the preparation of the RKA is still not based on the full RENJA.

c. From the analysis of the suitability of the RKA with the DPA of the Bappeda of Nagan Raya Regency in 2018-2020, it has proven very good and appropriate results. From the results of the analysis, it shows that the suitability between programs is $100 \%$ and the results of the analysis between activities are $100 \%$, which is a very good result, meaning that all programs and activities in the RKA and DPA are compatible between the two. This proves that the preparation of the DPA is based on the RKA completely.the results of the examination above, it appears that the highest consistency is in the RKA and DPA reports. All programs and activities in RKA and DPA are in sync. And for the suitability of PPAS and RENJA and RKA it is still not in sync because programs and activities are still not compatible between the texts.

From interviews obtained, it was found that there were discrepancies caused by several planned activities not being carried out due to technical constraints in the field as well as activities that were not accommodated and also low budget absorption due to delayed central transfers and also influenced by low human resources (HR). . 
From the results of the study of performance achievements in the Bappeda of Nagan Raya Regency, the 2018 fiscal year has been carried out well, in other words, 83.42\% have been realized. In the 2019 fiscal year it has also been carried out well despite obstacles due to low budget absorption caused by delayed central transfers, in other words only $69.31 \%$ has been realized and in the 2020 fiscal year the achievements have also been good, in other words it has been realized amounted to $95.54 \%$.

\section{Conclusions}

1. From the analysis of the suitability of PPAS with the RENJA of the Bappeda of Nagan Raya Regency in 2018-2020 it is quite good and appropriate. From the results of the analysis, it shows the suitability between $D$ programs as much as $87.5 \%$ while for the results of the analysis between activities as much as $89.6 \%$, which is a pretty good result, although there are some programs and activities that are still out of sync with each other, meaning that in The preparation of PPAS is still not based on the full RENJA. From the analysis of the suitability of the RENJA with the Bappeda RKA of Nagan Raya Regency in 2018-2020 it is quite good and appropriate. From the results of the analysis, it shows the suitability between programs as much as $83.39 \%$ while for the results of the analysis between activities as much as $84.97 \%$, which is a fairly good result, although there are several programs and activities that are still out of sync. each other, meaning that in the preparation of the RKA it is still not based on the full RENJA.

2. From the analysis of the suitability of the RKA with the DPA of Bappeda Nagan Raya Regency in 2018-2020, it has proven very good and appropriate results. From the results of the analysis, it shows that the suitability between programs is $100 \%$ and the results of the analysis between activities are $100 \%$, which is a very good result, meaning that all programs and activities in the RKA and DPA are compatible between the two. This proves that the preparation of the DPA is based on the RKA completely.

3. The highest consistency is in the RKA and DPA reports. All programs and activities in RKA and DPA are in sync. And for the suitability of PPAS and RENJA and RKA it is still not in sync because programs and activities are still not compatible between the texts.

4. From interviews obtained, it was found that the discrepancy was caused by several planned activities not being carried out due to technical constraints in the field as 
well as activities that were not accommodated and also low budget absorption due to delayed central transfers and also influenced by low human resources ( HR).

5. From the results of the study of performance achievements in the Bappeda of Nagan Raya Regency, the 2018 fiscal year has been carried out well, in other words, 83.42\% have been realized. In the 2019 fiscal year it has also been carried out well despite obstacles due to low budget absorption caused by delayed central transfers, in other words only $69.31 \%$ has been realized and in the 2020 fiscal year the achievements have also been good, in other words it has been realized amounted to $95.54 \%$.

6. implications for the consistency of planning and budgeting on performance achievements at the Regional Development Planning Agency of Nagan Raya Regency, namely the implementation of all performance targets that have been set.

\section{Bibliography}

Bappeda. ( 2018). Dokumen Pelaksanaan Perubahan Anggaran Satuan Kerja Perangkat Kabupaten. Kabupaten Nagan Raya. Nagan Raya.

Bappeda. (2019). Dokumen Pelaksanaan Perubahan Anggaran Satuan Kerja Perangkat Kabupaten. Nagan Raya.

Bappeda. (2020). Dokumen Pelaksanaan Perubahan Anggaran Satuan Kerja Perangkat Kabupaten. Nagan Raya.

Bastian, I. (2006). Sistem Perencanaan dan Penganggran Pemerintah Daerah Di Indonesia. Jakarta: Selemba empat.

BPKP, D. I. (2005). Pedoman Penyusunan Anggaran Berbasis Kinerja (Revisi). Jakarta: BPKP.

Meldayeni. (2011). Analisis Konsistensi Perencanaan dan Penganggaran Bidang Kesehatan di kota solok tahun 2007-2010. Padang: Universitas Andalas.

Pusat, P. (n.d.). Pemerintahan Daerah. Retrieved from https://peraturan.bpk.go.id/

Pusat, P. (n.d.). Sistem Perencanaan Pembangunan Nasional. Retrieved from https://peraturan.bpk.go.id/Home/Details/40694

Symond, D. (2006). Kajian Perencanaan dan Peganggaran Kesehatan Di Dinas Kesehatan Kota Padang Tahun 2006. 